Shifting Sands: Interpreting 'Developmental' Leadership in the Pacific Islands

Jack Corbett

State, Society and Governance in Melanesia

School of International, Political \& Strategic Studies

ANU College of Asia \& the Pacific

Australian National University

Canberra ACT 0200

AUSTRALIA

jack.corbett@anu.edu.au

Tel: +61261258394

Fax: +61 261255525

A slightly amended version of this paper is published in the journal Forum for Development Studies 40 (3) 491-510.

Acknowledgements: I would like to thank John Boswell, Patrick Vakaoti, Peter Larmour, Terence Wood, Sinclair Dinnen and two anonymous reviewers for their helpful comments on earlier versions of this paper. Any errors are of course my own. 


\section{Shifting Sands: Interpreting 'Developmental' Leadership in the Pacific Islands}

\section{Abstract}

The capacity for leadership, including political leadership, to improve development outcomes has attracted recent interest within development studies and associated donor agencies. This new approach is a welcome critique of the broadly institutionalist outlook of the good governance agenda, however there is a mismatch between the desire to 'bring the agency back in' and the commitment of the Developmental Leadership Program's (DLP) to positivism, and, despite claims to the contrary, structuralism. Instead, I argue that interpretivism, with its emphasis on the meanings and beliefs of human actors, can augment this approach by providing a fundamentally different view of the agency question that sits at the heart of the DLP's research program. To illustrate this point I draw from my own research into the life stories of politicians from the Pacific Islands. In contrast to the dead weight of multiple variables and formal laws, I find that political life is embedded within the distinctively human realm of interpersonal action and that while leaders implicitly believe in their own agency, they also commonly experience a sense of powerlessness that stems in no small part from the inherent contingency and uncertainty of all policy making.

Keywords: developmental leadership, interpretivism, Pacific Islands, framing, storylines, mobilising metaphors

\section{Introduction}

The capacity for leadership, including political leadership, to improve development outcomes has attracted recent interest within development studies and donor agencies (Rondinelli and Heffron 2009; Leftwich 2010; Leonard 2010; Melo et al. 2012; Persson and Sjöstedt 2012; Rotberg 2012). Historically, empirical studies of political leadership are notably absent from the discipline, in part reflecting donor discomfort with domestic politics (Hout and Robison 2009 use the term 'depoliticisation'). More recently, frustration with the broadly institutionalist outlook of the good governance agenda has led some scholars to reframe their analysis around the role of 'developmental' leaders, elites and coalitions in enhancing or 
undermining development outcomes. Adrian Leftwich ${ }^{1}$ (2010) argues that development studies has tended to focus on structural conditions that explain the failure of development, rather than the capacity (or what he calls agency) of leaders in particular to overcome systemic challenges. The emphasis is on identifying a leadership variable that can then be targeted with specific programs that aim to facilitate 'developmental' leadership. This theoretical perspective is also grounded in the experience of practitioners, and in particular the occurrence of so-called 'pockets of productivity' which anecdotally illustrate the capacity of leaders to overcome seemingly insurmountable barriers (for example see Leonard 2010).

In addition to its theoretical significance, in the Pacific Islands leadership also functions as a policy agenda with the Developmental Leadership Program (DLP) - currently funded by AusAID [Australia], Oxfam, Transparency International, The Asia Foundation and GIZ ${ }^{2}$ functioning as a research body, while organisations like the Pacific Leadership Program implement projects that aim to 'strengthen their [leaders] individual and organisational capacities as effective actors for positive developmental change'. ${ }^{3}$ And while the language is couched in terms of empowerment, it is implicitly reactive. If strong leadership is the cure, than weak leadership is the problem, with programs designed to address a sense of leadership decline. Perceived decline is also apparent in much of the popular 'talk' about politics and leadership in the Pacific region with commentators and activists rehearsing nostalgic recollections of strong, purposeful independence leaders. Combined, this policy problematisation is driven by one seemingly straight forward question: 'how can we fix political leadership in the Pacific Islands?'

I do not have an answer to this question, nor am I convinced by its apparent uncomplicatedness. Good leadership, like good governance, has no opponents. Nobody champions bad leadership. However, the apparent consensus that Pacific Islanders, and by extension all developing countries, need better leadership masks the diverse and subjectively held views about the different types of leadership required to achieve developmental aims. Specifically, I argue that the current research agenda is limited by its commitment to

\footnotetext{
${ }^{1}$ In the time between when this article was first written and published, Adrian Leftwich, who more than anybody has influenced the research agenda on leaders, elites and coalitions in development studies, sadly passed away. A lovely tribute to the man and his work by Steve Hogg, Adrian's collaborator on all things DLP, can be viewed here: http://www.dlprog.org/contents/about-us/adrian-leftwich.php

${ }^{2}$ See http://www.dlprog.org/contents/partners.php (accessed 11/9/2012)

${ }^{3}$ See http://www.plp.org.fj/ (accessed 27/08/2012)
} 
positivism $^{4}$ and, despite claims to the contrary, structuralism. In contrast, I outline how interpretivism, with its emphasis on understanding the meanings and beliefs that human actors hold, can augment this approach by providing a fundamentally different view of the agency question that sits at the heart of the DLP's research agenda.

I make three moves: firstly, I draw on the extant literature on politics in the Pacific Islands, and donor program documents, to map how different theories and actors in development frame the 'leadership problem'. In doing so I argue that a vision of 'ideal' leadership is implicitly embedded within each iteration of development theory and that these ideas already inform donor actions in the Pacific context; secondly, I outline how positivism offers limited insights into how these frames are translated into practice. By highlighting the fragmented vision of what constitutes ideal leadership, I demonstrate that the 'leadership problem' and the declining leadership storyline are self-fulfilling and serve to heighten rather than ameliorate frustration with contemporary leaders; and thirdly, I outline how an interpretive approach might reimagine this research agenda around its core agency question. In doing so I draw from my research on the life stories of politicians in the Pacific Islands to illustrate how interpretivism provides a fundamentally different picture of political leadership that stands in contrast to mechanistic and reified positivist models.

\section{What is Interpretivism?}

Interpretive research is based on the ontological conviction that actions and practices are shaped and framed by ideas held individually and collectively about the world (Bevir and Rhodes 2006; Yanow 2007; Bevir 2011; Schwartz-Shea and Yanow 2011). Leaders, in this view, encounter the context in which they find themselves through a veil of ideas - in the same way the scholars of politics do (Yanow and Schwartz-Shea 2010; Hay 2011). For interpretivists, the study of political life entails interpreting the beliefs and desires of human actors from 'within' existing governing traditions or webs of belief rather than attempting to sit 'outside' and make objective judgements (Bevir and Rhodes 2003: 18). The scholarly aim in interpretative research is understanding, generated by establishing the beliefs and

\footnotetext{
${ }^{4}$ Positivism (including logical-positivism, neo-positivism or post-positivism) is a broad and contested term employed in this article to describe scholars working to establish and test predictive models and formal laws about observable social phenomena. Two caveats: firstly, I acknowledge that there are major debates within this tradition but it can nevertheless be meaningfully distinguished from interpretivism on ontological and epistemological grounds; and secondly, while Leftwich and the DLP do not explicitly self-identify as positivists, I maintain that their work demonstrably internalises the positivist paradigm as illustrated by their preference for quantitative data and their desire to establish correlation and covariance between leadership and other variables.
} 
meanings which inform actions and practices embedded in traditions that bind 'situated agents' together in often unacknowledged inter-subjective communities that are open-ended and evolving (Hay 2011: 167). 'Situated agency', which I discuss in further detail below, refers to the capacity of individuals to reflect on their own beliefs and act for their own reasons, albeit the meanings and beliefs that inform their actions are embedded within a particular context or background of inherited traditions: humans can innovative but they are not autonomous (Bevir and Rhodes 2008: $171 \& 174$ ).

The literature on interpretivism, what it is, and what it means for the study of policy and politics, is extensive and it is beyond the scope of this piece to provide a comprehensive review. In relation to this article, the most important distinction is that interpretivism is founded on fundamentally different ontological and epistemological commitments to that espoused by positivism: it is typically based on constructivist-subjectivist rather than realistobjectivist prepositions (Yanow and Schwartz-Shea 2010: 33). Interpretivists critique the commitment of positivists to predictive modelling, formal laws, 'the separation of fact and value, and the splitting of description and explanation from critique and evaluation' (Glynos and Howarth 2008: 155). In contrast to reification, interpretivists seek to understand how people see and produce the world by exploring how meanings, beliefs and traditions inform their actions and practices. And while positivism is the dominant 'other', they also distance themselves from critical realists, institutionalists and post modernists on the grounds that these schools of thought also provide insufficient scope for human agency.

While different strands of interpretivism have different emphasis, in this article I am specifically concerned with the theoretical framework employed by Mark Bevir and R. A. W. Rhodes $(2002 ; 2003 ; 2006)$. The reference to 'shifting sands' in the title is an attempt to capture the dilemma that confronts positivist attempts to objectively measure leaders', or any human agents, 'room to manoeuvre'. I argue that this 'wriggle room' is constructed and reconstructed by the competing meanings and beliefs that human actors hold. Thus, in the context of 'developmental' leadership, agency is not a variable that can be isolated or controlled for, but must be understood as an individual's subjective or inter-subjectively held perceptions about the changes that they believe they can make in a given context. Consequently, given its aims, I argue that an interpretive approach can augment DLP analysis by providing a fundamentally different perspective on the important agency question it raises. 
Based on its positivist orientation, DLP assumes that the purpose of policy is to react to static and identifiable problems and then solve them. The problem, as it relates to leadership, exists outside the policy making process. Conversely, interpretivists assume that problems are endogenous to the policy making process - they exist within them and are produced by them: 'Policies give shape to 'problems'; they do not address them' (Bacchi 2009: x). To illustrate this point and to provide some background on the way leadership has been understood in the Pacific region, I interrogate different problem representations found in development theory and show how they reveal critical insights into the taken-for-granted assumptions that inform governing practices. I identify how the problem is framed, the proposed solution, and the key actors who seek to initiate change. Framing, a term synonymous with Erving Goffman's (1975) pioneering work, refers to 'an account of ordering that makes sense in the domain of policy and that describes the move from diffuse worries to actionable beliefs,' an 'internally coherent constellation of facts, values, and action implications' that contain a 'normativeprescriptive' story about what the problem is and what should be done about it (Hajer and Laws 2006: 256-257).

In contrast to anthropological studies of localised authority (for review see Watson-Gegeo and Feinberg 1996; McLeod 2008; Mosko 2012), Table 1 below provides an outline of how development theory has come to understand the development challenges Pacific Islanders face. ${ }^{5}$ And, while some frames are more dominant in different places and time periods, the beliefs that underpin them inform the policy interventions that island governments, donors and non-government organisations undertake in the region. Echoing Leftwich's (2010) assertion, for the most part leadership is not explicitly part of each problem representation and so the characterisation of how each frame conceptualises 'ideal' leadership is largely my interpretation of the implicit commitments made by each theory. As such, each frame should not be seen as variable but rather as a theoretical tradition that informs governing practices. Furthermore, all frames remain active in contemporary practice, with entitlement theory, for example, reenergising the focus on an active citizenry, previously employed by the basic needs frame, several decades after it was first identified as a development problem.

As with all heuristics, inevitably there a degree of crossover between frames. Explanations of institutional failure, for example, employ a variety of causal factors - including patronage, or

\footnotetext{
${ }^{5}$ A fantastic paper titled 'Policy perspectives and practices in Global South cities: A Study of Nairobi, Kenya' by Hamhaber, J, Kedogo, J and Macharia, M at the $7^{\text {th }}$ Annual Interpretive Policy Analysis Conference in Tilburg, 5-7 July 2012, provided the inspiration for this table.
} 
conflict between the cultural logics of modernism and traditionalism - while scholars who use the term 'hybridity' draw on both modernist and post-colonial interpretations to critique aspects of the good governance agenda (see Brah and Coombes 2000; Pieterse 2001; Clements et al. 2007). In addition, despite each frame positing a particular conceptualisation of 'ideal' leadership, individual leaders often change style and approach depending on their audience or purpose, just as followers anticipate leaders will conform to prevailing norms on designated occasions. Moreover, while this article is primarily concerned with explaining how development theory frames political leadership, it is important to note that there are also competing definitions of what development is (for review see Rist 2007; Rist 2009). The frames outlined below predominantly conceive of development in economic terms. The main exception is theology which more closely aligns with the secular conceptualisation of trusteeship (see Cowen and Shenton 1996). While largely absent from development theory, the theological frame is particularly important in the Pacific as, due to its extensive influence, it tends to be the avenue through which local calls for better leadership are directed.

Caveats aside, the aim of this heuristic is to bring conceptual clarity to what is otherwise a disparate field. In doing so I highlight the centrality of leadership to all of these debates; demonstrate how 'ideal' leadership models can be both contradictory and complimentary; and illustrate how global and local discourses, as translated into development vernacular, permeate and inform donor theory and practice. Consequently, while there is often a time lag between when debates emerge in development studies and the publication of Pacific casestudies, there is no reason to suggest that the 'leadership problem', as represented in the Pacific context, differs vastly from other parts of the world. 
Table 1: Framing Political Leadership in the Pacific Islands

\begin{tabular}{|c|c|c|c|c|c|}
\hline Frame & Problem & Key Actors & Intervention & Policy Mechanism & Ideal Leadership \\
\hline Modernism & $\begin{array}{c}\text { Traditionalism - The } \\
\text { centripetal authority of } \\
\text { national governments is } \\
\text { undermined by local politics, } \\
\text { micro-nationalist movements } \\
\text { and traditional power } \\
\text { structures. E.g. chiefs, } \\
\text { Sandline Crisis, Santo } \\
\text { Rebellion }\end{array}$ & National Governments & $\begin{array}{l}\text { Infrastructure Development } \\
\text { and Discretionary Funds }\end{array}$ & Legislative & $\begin{array}{c}\text { Visionary - Charismatic } \\
\text { Leadership Drives Change and } \\
\text { Progress }\end{array}$ \\
\hline Post-Colonial & $\begin{array}{l}\text { Neo-Colonialism - Foreign } \\
\text { governments and corporations } \\
\text { maintain control of the } \\
\text { political agenda. E.g. Post- } \\
\text { colonial readings of the Pacific } \\
\text { and Melanesian Ways, } \\
\text { promotion of tradition or } \\
\text { custom revival, Green } \\
\text { movement }\end{array}$ & $\begin{array}{l}\text { Local NGO's and activists, } \\
\text { National Governments }\end{array}$ & $\begin{array}{l}\text { Sovereignty, Self- } \\
\text { Determination and later } \\
\text { Cultural Heritage }\end{array}$ & Discursive / Constitutional & $\begin{array}{l}\text { Independent - Autonomous } \\
\text { Leadership Empowers Locally } \\
\text { Appropriate Forms of } \\
\text { Government }\end{array}$ \\
\hline Basic Needs & $\begin{array}{l}\text { Elite Domination - Self-serving } \\
\text { elites, conservative } \\
\text { manipulators of neo- } \\
\text { traditionalism. E.g. critique of } \\
\text { the 'Pacific Way' }\end{array}$ & NGO's, UNDP & $\begin{array}{l}\text { Voter and Parliamentary } \\
\text { Education }\end{array}$ & Civil Society / Legislative & $\begin{array}{c}\text { Responsive - Leadership is } \\
\text { Accountable to an Active } \\
\text { Citizenry }\end{array}$ \\
\hline Feminism & $\begin{array}{l}\text { Gender Disparity - Relative } \\
\text { absence of female leaders in } \\
\text { parliament and senior Cabinet } \\
\text { positions. E.g. quotas and } \\
\text { reserved seats for women }\end{array}$ & NGO's, UNWomen, CDI & $\begin{array}{l}\text { Positive Discrimination and } \\
\text { Candidate Training }\end{array}$ & Civil Society / Constitutional & $\begin{array}{l}\text { Representative - Leadership } \\
\text { Reflects a Cross-Section of the } \\
\text { Voting Public }\end{array}$ \\
\hline Neo-Liberalism & $\begin{array}{l}\text { Political Instability - The } \\
\text { unpredictable behaviour of } \\
\text { weak and self-interested } \\
\text { leaders undermines the } \\
\text { stability required to achieve } \\
\text { economic growth. E.g. votes- } \\
\text { of-no-confidence, coups }\end{array}$ & International NGOs (WB, ADB) & $\begin{array}{l}\text { Electoral Engineering and } \\
\text { Party Strengthening }\end{array}$ & Constitutional & $\begin{array}{l}\text { Technocratic - Networked } \\
\text { Leadership on Advice of } \\
\text { Experts and Evidence }\end{array}$ \\
\hline Globalism & $\begin{array}{l}\text { Weak States - Politicians are } \\
\text { unable to maintain law and } \\
\text { order, protect citizens and } \\
\text { deliver programs via state- } \\
\text { based institutions. E.g. } \\
\text { 'failed' or 'weak' states, 'arc- } \\
\text { of-instability' }\end{array}$ & RAMSI, Foreign Governments & $\begin{array}{c}\text { Law and Order (Strengthen } \\
\text { Police, Judiciary) }\end{array}$ & Institutional & $\begin{array}{l}\text { Authoritarian - Leadership is } \\
\text { Stable and Unchallenged }\end{array}$ \\
\hline $\begin{array}{c}\text { Good } \\
\text { Governance }\end{array}$ & $\begin{array}{l}\text { Corruption - Political elites } \\
\text { trapped by perverse } \\
\text { incentives (cultural or } \\
\text { material) that encourage } \\
\text { corruption. E.g. 'big man } \\
\text { politics', kerekere, } \\
\text { fa'asamoa, patronage and } \\
\text { clientelism }\end{array}$ & $\begin{array}{c}\text { International NGOs (WB, ADB, } \\
\text { TI, PIFS, CS) }\end{array}$ & $\begin{array}{l}\text { Oversight Bodies (Strengthen } \\
\text { Auditors, Ombudsman and } \\
\text { Leadership Codes) }\end{array}$ & Institutional & $\begin{array}{l}\text { Managerial - Leadership is } \\
\text { Transparent and Responsible }\end{array}$ \\
\hline Theological & $\begin{array}{l}\text { Ethical Malaise - Declining } \\
\text { moral values, combined with } \\
\text { increasing Asianisation, have } \\
\text { polluted political leadership. } \\
\text { E.g. Religious revival }\end{array}$ & $\begin{array}{l}\text { Evangelical and Pentecostal } \\
\text { Churches }\end{array}$ & Promote Religious Values & $\begin{array}{l}\text { Constitutional / Discursive / } \\
\text { Withdrawal }\end{array}$ & $\begin{array}{c}\text { Virtuous - Leadership } \\
\text { Demonstrates Integrity and } \\
\text { Trustworthiness }\end{array}$ \\
\hline
\end{tabular}


Much is made of the Pacific region's unique features, particularly the diversity of languages and cultures, and the economic challenges that face isolated and vulnerable small island states. However, despite rhetorical recognition of this distinctiveness, development needs in the Pacific are largely informed by the prevailing views of best practice that emanate or are transferred from the development enterprise (Larmour 2005). Accordingly, the different ways that development theory has framed the 'leadership problem' in the Pacific illustrates how the pursuit of an ideal form or type of leader is not new but is rather embedded within each frame and the intellectual tradition that it serves. Therefore, while I support Leftwich's (2010) claim that there is relatively little empirical research on leaders and leadership in developing countries - it should also be noted that in relation to politics and political leaders this is global phenomena (see Fenno 1990: 1; Kane and Patapan 2012: 11) - leadership is implicitly central to how policy interventions have been framed and implemented.

In his analysis of environmental policy, Maarten Hajer (1995: 12-13) wonders why actors with widely differing perceptions of what environmental politics is about, nevertheless sustain a particular way of framing the problem. What unites these disparate actors, Hajer argues, is the storylines that they employ which create a sense of order and unity. Declining leadership, as a storyline, masks the fragmented and contradictory ways that development theory and policy actors frame the 'leadership problem'. Consequently, good leadership functions as a hollow log - everyone agrees that it is a goal worth pursuing but there is little consensus about how the problem is defined, the types of interventions that will remedy it, and how we will know when success has been achieved. For example, the globalist frame, which sees the problem as weak states that undermine stability in the world order, values authoritarian leadership, which is largely irreconcilable to the precepts of a basic need frame. While both may share an emphasis on strengthening parliamentary functions, the latter views excessively authoritarian leadership as the problem, and instead offers responsive leadership as the solution.

While some frames are incompatible, it is important to note that Table 1 also illustrates how, under certain circumstances, there is a degree of complementarity between certain problem representations. The feminist and basic needs frames, for example, both conceive of the 'leadership problem' in terms of existing power relations which have, in effect, marginalised certain voices or members of society. Both place emphasis on active citizenship and education while the attributes of responsive and representative leadership are in broad 
ideological alignment (for example see George 2009). Similar inferences can be drawn by looking at which policy actors align with particular frames. Echoing the complementarity outlined above, it should come as no surprise that both civil society activists and the United Nations Development Programme actively employ the feminist and basic needs frame. Conversely, while the global emphasis on curbing corruption via oversight bodies in pursuit of a managerial form of leadership is championed by multilateral agencies, those who aspire to visionary leadership are likely to see this form of monitoring and accountability as excessive, and, in extreme cases like Vanuatu's Santo Rebellion or PNG's Sandline Crisis, argue that repressive means justify modernist/nationalist ends. Consequently, certain development actors are predisposed by the ways they frame problems to work with or against each other.

Having made these claims let me insert the following caveats that emerge from Table 1. Firstly, policy is not always made on the basis of a coherent and logical framing of the problem. Rather, as a hollow log, the definition of the 'leadership problem' is often useful in practice because it is vague and ambiguous, allowing policy actors to draw on multiple storylines to explain the rationale for interventions. In other words, these ideal representations do not necessarily mirror practice. Consequently, the 'how do we fix this leadership problem' question I highlighted at the beginning of the article becomes somewhat immaterial. As David Mosse (2004) argues, policy actors harmonise existing practice with policy storylines. Therefore, it should come as no surprise that much of the initial research by the DLP has focused on the role of education in supporting leadership capacity as this is one area where donors are already heavily active and is therefore easily justifiable (for selected examples see Brannelly et al. 2011; Leftwich and Wheeler 2011: 11; Theron 2012).

Similarly, while certain actors are known to support specific frames, some organisations are active in more than one. For example, AusAID, the largest aid donor to the Pacific, has a mandate to further Australia's national interest which sits most comfortably with the pursuit of stability emphasised by the globalism frame, but it also willingly funds projects across the entire spectrum of problematisations. In part, we can infer, this is because different areas of the department believe more strongly in different frames, but it also illustrates that policy actors have second and third order priorities. In other words, as a hollow log, the leadership storyline justifies funding to a wide range of projects despite AusAID's mandated focus on the national interest. 
There are a number of ways we can interpret this ambiguity. Given that actors frame the 'leadership problem' differently, policy interventions do not always fall into neat categories. This means that many are at best incompatible and at worst contradictory. From this perspective, while 'developmental' leadership exudes positive connotations, beneath the veneer its foundations are built on shifting sands - impossible to pin down and implicitly changeable. That is, refining our definition of 'developmental' leadership will not solve the problem of multiple and contested framing - I want to make it clear that I am in no way blaming conceptual slippage. Rather, as I have illustrated, the current declining leadership storyline could mean one or several conflicting leadership ideals, while there is little consensus for how this transformation should transpire, nor is there ever likely to be.

This contestation is not necessarily undesirable given that practical 'messaging' about leadership and development is one of DLPs core aims (Leftwich and Wheeler 2011: 5). As a hollow log, 'developmental' leadership can serve an important function in the policy process by uniting disparate actors around a common storyline or 'mobilising metaphor' (Mosse 2004: 663). As outlined, it can allow policy actors to articulate a rationale for interventions that may not fit within mandated fields like the 'national interest'. However, it is also important to recognise that when seeking to operationalise frames, including measuring their outputs, definitional dexterity becomes problematic as policy actors hold different beliefs about policy goals and how they should be reached. Targeted polices might conceivably solve the problem as certain actors frame it, but the plurality of frames means that the purpose of leadership will always be disputed, in part because the degree of agency individuals have is itself contentious. Consequently, unless we focus our analysis on how leaders, elites and coalitions view the world, and consider how their meanings and beliefs inform their actions in a given context, recognising agency becomes a form of self-imposed bondage - a mechanism for blaming inequalities, which often have deep historical roots, on contemporary leaders. Rather than increasing their legitimate capacity, and by extension the legitimate capacity of the institutions they represent, logically this problematisation must undermine it, fuelling anti-political sentiment and the perpetual search for better leaders.

The 'rules of the game', as Harold Lasswell's (1951) famous maxim reminds us, decide who gets what, when and how. But they are not fixed. Rather, politics is a perpetual contest between ideas and beliefs about what appropriate rules are - including definitions of 'developmental' and 'predatory' - and political leaders are key players in this ongoing 
debate. Consequently, while Leftwich (2010) and I may agree that understanding the politics of development is important, the standard positivist response to contested meanings and beliefs is predicated on its realist-objectivist aims: that by collecting more evidence we can better refute or support each claim. As an interpretivist I would respond by arguing that leadership, be it 'developmental' or otherwise, does not have intrinsic properties or objective boundaries (Bevir 2011: 188) - as Table 1 demonstrates - and that this search for a solution to contested meanings and beliefs is particularly problematic in the context of democratic politics as leaders are compelled to constantly negotiate the problem of their own legitimacy by simultaneously reaffirming the sovereignty of the people even while enjoying the benefits of leadership (Kane and Patapan 2012: 2).

That is, any attempt to define what constitutes 'developmental' leadership is not outside politics but is inherently the subject of it, as influential leadership theorist James McGregor Burns (2005: 12) argues:

When people call for leadership, or deplore the lack of leadership, they see it not only as a needed spur to human progress but as in itself a moral and ethical entity and a necessary gauge of action. Leadership, in short, becomes an activist as well as an academic enterprise.

Consequently, paying greater attention to the 'agency' or capacity of 'mobilising' or what Burns (1979) would call 'transformative' leaders, elites and coalitions to solve development challenges has limitations not the least of which is that the contested nature of what constitutes 'ideal' leadership inevitably accentuates the very sense of decline apparent in calls for better leadership. As such, there can be no realist-objectivist solution to the leadership question as those dissatisfied with the outcomes of political processes will always call for more enlightened leaders.

\section{'Developmental' Leadership Reconsidered}

At the beginning of the article I advanced two arguments: firstly, that despite a relative absence of empirical research, a vision of ideal leadership is implicitly embedded within all problematisation frames that permeate development theory and practice; and secondly, that fragmented and contradictory views about what constitutes good or 'ideal' leadership means that it is an impossible problem to 'fix', in part because the degree of agency individuals have is itself contentious. For the remainder of the article I want to flesh out the latter 'agency' part 
of this argument with one important disclaimer. The 'developmental' leadership agenda, as defined by Leftwich (2010: 103), is explicitly interested in the organisation and mobilisation of people and resources to overcome collective action problems, and as such his definition of leadership could include leaders from the public, private or civil society sectors. Conversely, in this article I primarily focus on politics and political leadership. In many respects this distinction is false as distinguishing between leadership types - political, religious, commercial - is problematic in the Pacific where leaders tend to occupy multiple roles and assume overlapping identities (Corbett 2012). However, it is feasible that what constitutes 'developmental' leadership for a commercial enterprise or public corporation, for example, is less contested than the description presented here.

DLP's aims in relation to leadership are diverse but at the centre of their agenda is a desire to bring 'agency back in' to development theory and practice. This view is based on a critique of the technocratic nature of conventional development practice which, Leftwich (2010) argues, ignores the primacy of politics and the role of leaders, elites and coalitions in particular. I largely agree with this critique of contemporary development theory and practice and as such I welcome DLP's efforts to pursue this research agenda. However, despite the relevance of their approach, DLP runs the risk of falling into the same trap by understating the role that ideas and values play in shaping political outcomes. In particular, echoing DLP's positivist commitments, their list of 'working hypothesis' (Leftwich 2010: 105-106) seek to determine the capacity of agents to shape their environment. For example, Monique Theron's (2012) work for DLP on African heads of state seeks to establish the contribution of leadership to higher growth rates and democratisation processes. She finds a correlation between those African countries with high growth rates and democratisation processes, and highly educated and mature leaders with diverse career histories. This is a very interesting piece of research but while it may tell us something about the structural dynamics of elite rule, it tells us very little about agency in the way interpretivsts understand it (think terms like 'life world', 'world view' or 'inner life'). We don't learn, for example, about how leaders perceive the influence of their education, age or career on their capacity to govern. Rather than fluid and inter-subjective meanings and beliefs held by human actors, agency, from this perspective, is a lifeless and somewhat fleeting variable that is virtually impossible to isolate and measure. Consequently, despite their commitment to demonstrating that agency and leadership are anchored in formal or informal structures of power and authority, ultimately their commitment to positivism leads them to privilege structuralist explanations. 
The Theron example is not a one-off - there have been a number of other recent attempts to understand the role that leaders play in delivering development outcomes (see Melo, Ng'ethe et al. 2012; Rotberg 2012). However, while these books may offer excellent accounts of how leaders seek to initiate and sustain change, they still provide a dilemma for positivists: they cannot produce the predictive, unbiased, generalisable models they privilege and as a result they leave those who seek to answer DLP's research questions dissatisfied - as demonstrated by Eduard Grebe's $(2012 ; 2013)$ reviews. Like political biography, these studies allow us to better understand the different strategies leaders employ to 'manoeuvre at the margins' and why they employed them. We can even extend their more nuanced understanding to a critique of technocratic development assistance and other programmatic reform attempts, but they cannot validate DLP's hypothesis. If anything, given their preference for examining successful cases, they provide more questions than answers.

As stated above, I largely agree that technocratic attempts to engineer institutional solutions will not help us to understand the primacy of politics and the role of leaders, elites and coalitions in determining development outcomes. Moreover, I essentially endorse Leftwich's (2010: 95) desire to eschew the 'great man/women of history' tradition and analysis that emphasises the personal characteristics of the people involved. The issue I have with DLP's approach is that it runs the risk of being similarly mechanistic due to the internalisation of the positivist paradigm. Essentially their argument boils down to a belief that if we get the mix of leaders, elites and coalitions 'right', in the 'right' circumstances (defined as critical junctures, 'triggers' and windows of opportunity) we will get a 'developmental' outcome. This view of development mechanisms is not vastly different than that espoused in previous theories that they distance themselves from. The language has simply changed from institutions to leaders, elites and coalitions. DLPs recognition of 'framing' (Leftwich and Wheeler 2011: 10) is welcome but it is still premised on the need to make leaders think like donors. Rather, I argue, donors need to think more like leaders. However, to do so we need a fundamentally different view of the structure-agency problem.

In his key paper where he outlines DLP's research agenda, Leftwich (2010: 93) opens with Karl Marx's famous maxim that 'Men make their own history, but they do not make it just as they please'. There is a somewhat paradoxical beginning as the decision to employ Marx, one of philosophies' great structuralist thinkers, alerts us to the possibility that, contrary to their claims, DLP is in fact primarily interested in understanding the structural dynamics of elite 
rule, not agency. Indeed, Leftwich (2010: 93) says as much: 'we have to understand much better the forms and functions of different patterns of 'leadership', anchored as all such patterns are in formal or informal structures of power and authority'. What is more, given its positivist commitments, this is the only way it can conceive of the role of leaders, elites and coalitions in the development process - the emphasis on predictive laws and explanations leaves little room for inter-subjective meanings. As such, it should come as no surprise that his definition of 'developmental' leadership is similarly mechanistic:

Developmental leadership is an inherently political process involving the organisation and mobilisation of people and resources in pursuit of particular goals, in given institutional contexts of authority, legitimacy and power (often of a hybrid kind). Achieving these goals, and overcoming the collective action problems which commonly obstruct their achievement normally requires negotiating locally appropriate institutions by formal or informal coalitions of interests, elites and organisations, both vertical and horizontal. (Leftwich 2010: 103)

That is not to say that understanding the interplay between economic and social forces and elite rule is not a worthy research aim - it is a welcome addition to development thinking. Nor do I seek to conflate structuralism and positivism ${ }^{6}$ - although I maintain there is a natural affinity between the two that largely stems from the preference of the latter for quantifiable data. However, these caveats aside, I also believe that the agency question that Leftwich (2010: 93) rightly raises is far too important to be ignored and therefore rather than jettisoning it in favour of a revised structuralist approach, I instead illustrate how interpretivism and 'situated agency' can offer useful insights.

\section{Reimagining Research on Leaders, Elites and Coalitions}

So where should we start? Firstly, to understand agency we must understand agents. Not just who they are in terms of biographical characteristics, or comparatively by analysing their role in creating 'developmental' states, but the meanings and beliefs that inform leadership practices. Agency, or 'situated agency', cannot be measured. It does not conform to predictive models. It is implicitly concerned with the subjective and inter-subjective

\footnotetext{
${ }^{6}$ Critical realists, for example, might share my emphasis on contested meanings while still holding to the belief that some narratives come closer to describing objective or material facts than others. That is, they see the relationship between structure and agency as dialectical with each having independent causal power - although they tend to see structure as having relatively more power than agency (see Marsh 2009).
} 
meanings and beliefs that human actors hold. These meanings and beliefs do not exist in a vacuum but are instead informed by historical traditions. These traditions, however, cannot be seen as equivalent to natural phenomena (Bevir and Rhodes 2008: 172). Rather, in contrast to rational actor models, an interpretive approach emphasises that we need to understand in what ways the meanings and beliefs that leaders hold shape how they see and produce the world (for review see Hay 2011: 175-178) - an interpretive approach does not ask how much capacity leaders have, but how much they believe they have. The emphasis is less on the action and more on the meanings of the action, the beliefs that underpin it, and the traditions within which it is situated (Bevir 2011: 189). Consequently, we need to know what motivates leaders, what they aim to achieve, how they set about getting it, and what they sacrifice in the process. We need to understand how they see their social networks and interpersonal relationships, the organisations they are a part of, the obligations they incur and the opportunities they perceive. Moreover, we need to explore the temporal dimensions of leadership practice. In the post-colonial Pacific, ideas like the Pacific and Melanesian Ways were an attempt to articulate how that generation saw leadership, but is there a contemporary manifestation? What do young emerging leaders think? The declining leadership storyline sees them as comparatively weak, but presumably this is not their self-perception.

Secondly, it is easy to think of leadership as a problem that exists 'out there', in the periphery, beyond universities, donor offices and urban centres. But how do current donor theories impact contemporary leadership? This is the question I have attempted to address in Table 1 which shows that many of the frames have included substantial investment in leadership capacity with education scholarships, for example, offered to future leaders since the 1950s. What impact have these ideas had? Before trying to 'fix' leaders, perhaps we should ask how the meanings and beliefs that inform current programs and projects already make or break leadership cadres and coalitions.

Furthermore, as I have demonstrated, donors have always supported a particular vision of 'developmental' leadership, while the inclusive and ambiguous nature of the current project means that it can be used to justify almost any form of existing donor practice. Consequently, one role for the DLP and its partners might be to resist the push to operationalise this new storyline. Rather, by reimagining and sustaining a 'mobilising metaphor' about what is and is not possible under human endeavour in a given context, we allow development practitioners to interpret and reinterpret their projects in ways that sanction compromise and the enrolment 
of diverse interests (Mosse 2004: 663). Indeed, how actors, including leaders, frame the problem, or articulate a particular storyline, is itself an expression of agency - our actions not only create the social world but they produce the beliefs on which we act (Hajer 1995: 56; Bevir 2011: 188).

\section{Seeing Like a Leader}

If agency is largely a matter of perception, reflecting and constituting subjectively and intersubjectively held meanings and beliefs, than the role for scholars working in an interpretive tradition is not to measure or quantify what constitutes 'room to manoeuvre', or determine where structures end and agency begins, but to ask how agents perceive change and understand how they see their capacity to initiate and sustain it. Consequently, the most important impact that DLP's research agenda can have on development practice is to assist donors to appreciate how leaders see the world. To conclude this article I draw from my own research on the life stories of politicians in the Pacific Islands, comprising of around 100 indepth biographical interviews, 40 published life histories, and observation-based research, to illustrate how an interpretive approach would answer some of the questions the DLP raise. This is a broad book-length project and so a full review of its findings is beyond the scope of this article. For now, I predominantly focus on what this perspective can tell us about agency. The reference to 'seeing like a leader' draws explicitly from James C. Scott's (1998) book with a similar title and in particular his belief in the importance of recognising the power of practical knowledge in all public policy endeavours.

Politicians implicitly believe in their own agency. If they did not think they could make a difference in the lives of their families, communities and countries why else would they seek public office? But, what also emerges from their accounts of everyday political life is that they experience a sense of powerlessness: that despite their aims and ideals they do not believe that they act in a world that is completely under their control. Specifically, they characterise politics and public policy making as persistently beset by problems of contingency and what Mark Philp (2007) calls 'indeterminacy'. In contrast to lifeless variables and rational actor models, I find that parliamentary decision-making is embedded within the distinctively human dimensions of interpersonal action. Politicians describe political life as being beset with perpetual uncertainty, as opposed to calculated risk, about the intentions of voters, constituents, colleagues and opponents. From this perspective, 
politics is not merely about the relationship between structure and agency but explicitly concerns competing agencies and multiple structures.

One reflection is that this feeling is magnified in the Pacific context where large scale popular opinion polling, for example, is relatively absent. High levels of incumbent turnover also indicate that it is often difficult for politicians to gauge the mood of their electorate. Conversely, politicians are embedded within the social and political life of the communities they represent, with those from smaller constituencies in particular often able to have a personal relationship with every voter. Moreover, while the sense of 'being owned' by voters is common to politicians everywhere, in the Pacific politician's believe that they experience greater and more personalised demands on their resources than their colleagues from around the world.

This depiction of policy making as a form of bargaining, where networks of policy actors engage in an interdependent process of governance, is a feature of Rhodes' (2011) and Tiernan and Weller's (2010: 90-91) account of ministerial life in Britain and Australia where the euphoria of winning government is quickly tempered by ministers' realisation of their relative unpreparedness and the complexities of policy making. It also alerts us to the fact that in the struggle to obtain office politicians tend to inflate its authority, establishing high expectations amongst voters and supporters (Philp 2007: 109). Once elected, they confront the limits on their time, their influence, and are constrained by conflicting and legitimate interests and agendas of people with all the vices and virtues of humanity. Moreover, the aspirations and expectations of voters can be magnified by the normative imperatives of development discourse which sustains a desire for improvement and change that politicians believe they are not always in a position to deliver.

That is not to say that we should treat politicians as a homogenous group - quite the opposite. Reflecting their interests and skills, ambitions and aspirations, politician's preference certain roles over others. Attempts to map the plurality of people in parliament or the legislature have generated various typologies that seek to differentiate between politicians, both in terms of their pre-political pathways or trajectories and their behaviour once they enter the legislature (Barber 1965; Headey 1974; Weller and Grattan 1981; Searing 1994; Tiernan and Weller 2010). These studies find that some politicians are more interested in advocacy while others are more administratively minded. Some are ambitious but many are content just to watch the 
drama. But while all are different, they are nevertheless united by a common humanity: they have hopes and fears, doubts and convictions, pleasures and pains.

Combined, these insights about political life offer a fundamentally different view of leadership in development contexts. Rather than a distinction between structure and agency, we see that leaders are constantly shaping and reshaping the meanings and beliefs they ascribe to their work. Their preferences are not fixed but instead change in response to what Bevir and Rhodes (2008) call 'dilemmas' that emerge from conflicts between individual practices and the traditions in which they are embedded. Most importantly, we see that leadership is embedded within the distinctively human realm of interpersonal action. This perspective stands in stark contrast to the dead weight of multiple variables, predictive modelling and formal laws that characterise positivist research. Rather, it recognises that leadership, like development, is a human endeavour - that political institutions are created and sustained by the ideas that people who inhabit them hold about the world.

\section{Conclusion}

The extent to which human beings can alter and even transform their environment is of perpetual interest to social scientists. It is the question that sits at the heart of the structureagency debate that has recently assumed prominence in development theory where Leftwich (2010) argues we should look beyond institutions and pay greater attention to the capacity or 'agency' of leaders and their ability to effect 'developmental' change. As a contribution to this debate, I have outlined the conceptual limitations of 'developmental' leadership and its associated policy agenda by illustrating the different models of leadership espoused by development theory in the Pacific Islands - many of which are incompatible. I argued that this storyline functions like a hollow log by allowing actors to project consensus on what is otherwise shifting sand - a messy and contingent world of practice. In doing so I have shown how different frames in development studies reflect changes in mainstream disciplines. Following Bacchi (2009), I have demonstrated that the 'leadership problem' is endogenous to development studies and reflects its history and tradition of thought, informed by continuous interaction with donor practice. Accordingly, representations of the problem tell us more about this history of 'failures' and theoretical reinventions, than it does about the apparent successes or shortcomings of leaders or leadership. 
While I endorsed the call for greater empirical focus on leaders, elites and coalitions, I argued that the DLP's reliance on a positivist ontology and epistemology limits its ability to tackle the core agency question it poses. I argued that it has instead sought to explain the structural dynamics of elite rule. This is a worthy endeavour, however, I also maintained that the agency question that Leftwich (2010) raises is too important to ignore. I illustrated that an interpretivist approach, with its emphasis on understanding the meanings and beliefs of human actors, and the idea of 'situated agency' as espoused by Bevir and Rhodes (2003; 2006; 2010), offers one way out of this dilemma. Specifically, it refocuses our attention on how political leaders see the world. In doing so I drew on my own work on politicians in the Pacific Islands to demonstrate the fundamentally different perspective that this type of approach can bring to development thinking. I provided a picture of parliamentary decisionmaking embedded within the distinctively human dimensions of interpersonal action. I showed that, contrary to the popular image they like to portray, and reflecting an implicit belief in their own agency, politicians rarely act in a world that is under their control. In the broadest sense, this latter view of the structure-agency question is not incompatible with Leftwich's (2010) belief that leadership is anchored in broader power structures. But when we drill deeper an interpretive perspective provides a fundamentally different view of human action - rather than seeing a person's capacity to shape their environment as something that can be measured, interpretivists see actions and practices as linked in inter-subjective ways to the meanings and beliefs that human actors hold about the world, albeit these are situated in the context of competing agencies and governing traditions. 


\section{Bibliography}

Bacchi, C. (2009). Analysing Policy: What's the problem represented to be?, Pearson, Australia.

Barber, J. D. (1965). The Lawmakers: Recruitment and Adaptation to Legislative Life. New Haven and London, Yale University Press.

Bevir, M. (2011). "Public Administration as Storytelling." Public Administration 89(1): 183195.

Bevir, M. and R. A. W. Rhodes (2002). Interpretive Theory. Theory and Methods in Political Science. D. Marsh and G. Stoker. Basingstoke, Palgrave MacMillan.

Bevir, M. and R. A. W. Rhodes (2003). Interpreting British Governance. London, Routledge.

Bevir, M. and R. A. W. Rhodes (2006). Governance Stories. London and New York, Routledge.

Bevir, M. and R. A. W. Rhodes (2008). "Author's Response: Politics as Culutral Practice." Political Studies Review 6: 170-177.

Brah, A. and A. E. Coombes, Eds. (2000). Hybridity and its Discontents: Politics, Science and Culture. London, Routledge.

Brannelly, L., L. Lewis, et al. (2011). "Learning and Leadership: Exploring the linkages between higher education and developmental leadership." Developmental Leadership Program Research Paper 18.

Burns, J. M. (1979). Leadership New York Harper And Row.

Burns, J. M. (2005). "Leadership." Leadership 1(1): 11-12.

Clements, K. P., V. Boege, et al. (2007). "State Building Reconsidered: the Role of Hybridity in the Formation of Political Order." Political Science 59(1): 45-56.

Corbett, J. (2012). "'Two Worlds?' Interpreting Leadership Narratives in the 20th Century Pacific." Journal of Pacific History 47(1): 69-91.

Cowen, M. and R. Shenton (1996). Doctrines of Development. London and New York, Routledge.

Fenno, R. (1990). Watching Politicians: Essays on Participant Observation, IGS Press.

George, N. (2009). "'Situating' active citizenship: historical and contemporay perspectives of women's organising in the Pacific." Development in Practice 19(8): 981-996.

Glynos, J. and D. Howarth (2008). "Structure, agency and power in political analysis: Beyond contextualised self-interpretations." Political Studies Review 6(2): 155-169.

Goffman, E. (1975). Frame analysis : an essay on the organization of experience Harmondsworth Penguin.

Grebe, E. (2012). "Review of Transformative Political Leadership: Making a difference in the developing world." Developmental Leadership Program.

Grebe, E. (2013). "Review of Against the Odds: Politicians, Institutions and the Struggle Against Poverty." Developmental Leadership Program.

Hajer, M. (1995). The Politics of Environmental Discourse: Ecologial Modernization and the Policy Process. Oxford, Clarendon Press.

Hajer, M. and D. Laws (2006). Ordering Through Discourse. The Oxford Handbook of Public Policy. M. Moran, M. Rein and R. Goodin. Oxford, Oxford University Press.

Hay, C. (2011). "Interpreting Interpretivism Interpreting Interpretations: The New Hermeneutics of Public Administration." Public Administration 89(1): 167-182.

Headey, B. (1974). British Cabinet Ministers: The Roles of Politicians in Executive Office. London, George Allen and Unwin Ltd.

Hout, W. and R. Robison, Eds. (2009). Governance and the Depoliticisation of Development. New York, Routledge. 
Kane, J. and H. Patapan (2012). The Democratic Leader: How Democracy Defines, Empowers, \& Limits its Leaders. Oxford, Oxford University Press.

Larmour, P. (2005). Foreign flowers: institutional transfer and good governance in the Pacific Islands, University of Hawai'i Press.

Lasswell, H. D. (1951). The Political Writings of Harold D. Lasswell. Glencoe Illinois, The Free Press.

Leftwich, A. (2010). "Beyond Institutions: Rethinking the Role of Leaders, Elites and Coalitions in the Institutional Formation of Development States and Strategies." Forum for Development Studies 37(1): 93-111.

Leftwich, A. and C. Wheeler (2011). Politics, Leadership and Coalitions in Development: A Research and Policy Workshop Report. the First Developmental Leadership Program Research and Policy Workshop. Frankfurt.

Leonard, D. K. (2010). "'Pockets' of Effective Agencies in Weak Governance States: Where are they Likely and Why Does it Matter?" Public Administration and Development 30: $91-101$.

Marsh, D 2009, Keeping ideas in their place: in praise of thin constructivism, Australian Journal of Political Science 44(4): 679-96.

McLeod, A. (2008). "Leadership Models in the Pacific." State, Society and Governance in Melanesia Discussion Papers 6.

Melo, M. A., N. Ng'ethe, et al. (2012). Against the Odds: Politicians, Institutions, and the Struggle Against Poverty, Columbia University Press.

Mosko, M. S. (2012). The Making of Chiefs: 'Hereditary Succession', Personal Agency and Exchange in North Mekeo Cheifdoms. The Scope of Anthropology. L. Dousset and S. Tcherkezoff. New York and Oxford, Berghahn Books.

Mosse, D. (2004). "Is Good Policy Unimplementable? Reflections on the Ethnography of Aid Policy and Practice." Development and Change 35(4): 639-671.

Persson, A. and M. Sjöstedt (2012). "Responsive and Responsible Leaders: A Matter of Political Will?" Perspectives on Politics 10: 617632.

Philp, M. (2007). Political Conduct. Cambridge, Massachusetts, and London, England, Harvard University Press.

Pieterse, J. N. (2001). "Hybridity, So What?" Theory, Culture \& Society 18(2-3): 219-245.

Rhodes, R. A. W. (2011). Everyday Life in British Government. Oxford and New York, Oxford University Press.

Rhodes, R. A. W. and M. Bevir (2010). The State as Cultural Practice. Oxford and New York, Oxford University Press.

Rist, G. (2007). "Development as a Buzzword." Development in Practice 17(4/5): 485-491.

Rist, G. (2009). A History of Development: From Colonial Origins to Global Faith. London, Zed Books.

Rondinelli, D. A. and J. M. Heffron, Eds. (2009). Leadership for Development: What Globalisation Demands of Leaders Fighting for Change, Kumarian Press.

Rotberg, R. I. (2012). Transformative Political Leadership: Making a Difference in the Developing World, University of Chicago Press.

Schwartz-Shea, P. and D. Yanow (2011). Interpretive Research Design: Concepts and Processes, Routledge.

Scott, J. C. (1998). Seeing like a state: how certain schemes to improve the human condition have failed. New Haven, Yale University Press.

Searing, D. (1994). Westminster's World. Cambridge, Massachusetts and London, England, Harvard University Press. 
Theron, M. (2012). "Emerging and Non-Emerging African Countries: A Statistical Exploration of the Leadership Factor." Developmental Leadership Program Research Paper 19.

Tiernan, A. and P. Weller (2010). Learning to Be a Minister: Heroic Expectations, Practical Realities. Melbourne, Melbourne University Press.

Watson-Gegeo, K. A. and R. Feinberg, Eds. (1996). Leadership and Change in the Western Pacific. London, The Athlone Press.

Weller, P. and M. Grattan (1981). Can Ministers Cope? Melbourne, Hutchinson Group.

Yanow, D. (2007). Qualitative-Interpretive Methods in Policy Research. Handbook of Policy Analysis: Theory, Politics and Methods. F. Fischer, G. J. Miller and M. S. Sidney. Boca Raton, CRC Press.

Yanow, D. and P. Schwartz-Shea (2010). "Interpretive Research: Characteristics and Criteria." Revue internationale de Psychosociologie 15(35): 29-38. 